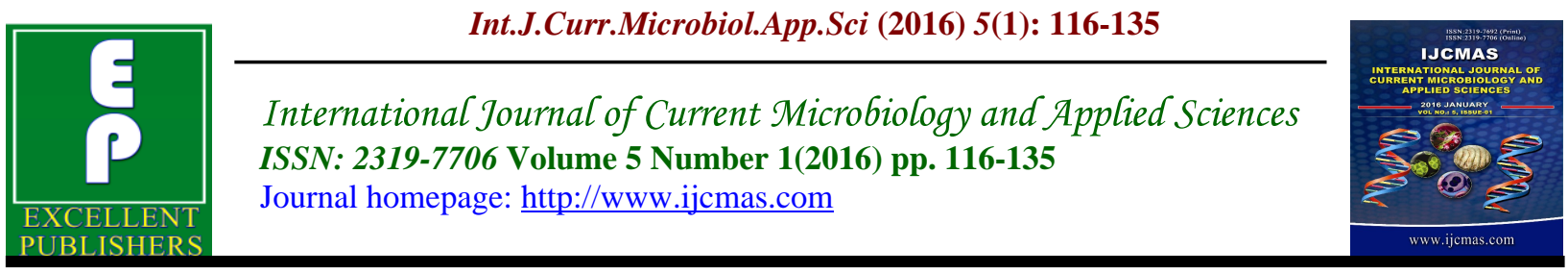

Original Research Article doi:

\title{
Barley Nitrogen Acquisition as Affected by Water Regime, Fertilizer Rates and Application Mode Using ${ }^{15} \mathrm{~N}$ Stable Isotope
}

\author{
Samak $^{1}$, R.R. Magdy, El.I. Gaber ${ }^{1}$, Y.G.M. Galal ${ }^{2} *$ and M.A. Mohamed ${ }^{2}$ \\ ${ }^{1}$ Department of Natural Resources, Institute of African Research and Studies, Cairo University \\ ${ }^{2}$ Atomic Energy Authority, Nuclear Research Center, Soil and Water Research Department, \\ Abou Zaabal, 13759 Egypt \\ *Corresponding author
}

\section{Keywords}

Application mode, Barley growth, Irrigation system, Mineral fertilization, Nitrogen, Tracer technique.

\section{Article Info}

Accepted: 08 December 2015 Available Online: 10 January 2016

\section{A B S T R A C T}

A lysimeter experiment was constructed to evaluate the acquisition of nitrogen fertilizer applied in different rates and splitting doses (mode) by barley crop grown on sand soil under different irrigation water regime. Every lysimeter was backed with $90 \mathrm{~kg}$ of experimental sand soil. Fertilizer nitrogen as ammonium sulfate form enriched with $2 \%{ }^{15} \mathrm{~N}$ atom excess was applied at rates of $120 \%$ (equal to $187.2 \mathrm{~kg} \mathrm{~N}^{-1}$ or $10.51 \mathrm{~g} \mathrm{~N} \mathrm{lys}^{-1}$ ), $100 \%$ (equal to $156 \mathrm{~kg} \mathrm{~N}^{-1}$ or 8.76 $\mathrm{g} \mathrm{N} \mathrm{lys}^{-1}$ ) and $80 \%$ (equal to $124.8 \mathrm{~kg} \mathrm{~N} \mathrm{ha}^{-1}$ or $7 \mathrm{~g} \mathrm{~N} \mathrm{lys}^{-1}$ ) of the recommended rate $(65 \mathrm{~kg} \mathrm{~N}$ $\left.\mathrm{fed}^{-1}\right)$. Nitrogen fertilizer rates were splitted into three modes of application as following: 33, 33, $33 \% ; 40 \%, 30 \%, 30 \%$ and $50 \%, 25 \%, 25 \%$. Three irrigation regimes: $60 \%, 80 \%$ and $100 \%$ of crop evapotranspiration (ETc). Straw yield was enhanced by of nitrogen fertilizer at N2 rate applied with S1 or S3. Plants irrigated with W1 followed by W3 water regimes achieved the remarkable values of straw yield. Root dry weight mainly significantly positively affected by irrigation water regimes and $\mathrm{N}$ fertilizer rates but not by mode of application. Irrigation with $\mathrm{W} 2$ regime combined with either $\mathrm{N} 2$ or N3 fertilizer rates applied at S3 splitting doses resulted in higher grain yield than other treatments. Application of W3 (60\%) regime reflected straw-N uptake higher than those recorded with W2 but nearly closed to those of W1 regime. The overall means of $\mathrm{N}$ uptake by roots indicated superiority of $\mathrm{N} 1$ rate and splitting mode S3 but gradually decreased with $\mathrm{N} 2$ and N3 rates. Water regime $\mathrm{W} 1$ interacted with either N1 or N2 achieved the best values of $\mathrm{N}$ uptake by grains. The grand mean of $\mathrm{N}$ uptake by grains as affected by application modes pointed out no big significant difference between them. Nitrogen derived from fertilizer (Ndff) by straw was fluctuated due to splitting modes but generally, percentages of Ndff don't exceed $29 \%$ from the total $\mathrm{N}$ uptake by straw. There are no clear cut evident between water regimes when Ndff absolute values was considered. Ndff by roots was very low and values didn't reflect any significant difference between the tested treatments. Combined treatment of $\mathrm{W} 1 \times \mathrm{xN} 2 \mathrm{xS} 3$ was the best where it gave the remarkable Ndff values gained by grains as indicated by overall means of the tested factors. Generally, \%NUE by straw of plants fertilized with $\mathrm{N} 1\left(187.2 \mathrm{~kg} \mathrm{~N} \mathrm{ha}^{-1}\right)$ rate surpass that of $\mathrm{N} 2\left(156 \mathrm{~kg} \mathrm{~N} \mathrm{ha}^{-1}\right)$ and N3 $\left(124.8 \mathrm{~kg} \mathrm{~N} \mathrm{ha}^{-1}\right)$, rates. This holds true with different water regimes. Efficient use of $\mathrm{N}$ fertilizer as affected by water regime was equal in W1 and W3 (34.1\%) and both were higher than W2 regime. Splitting dose mode superiority was dependent on water regime whereas \%NUE of straw enhanced by S3 under W1 and W3 regimes while it was lower with W2 regime. Similar trend, but to somewhat low extent, was noticed with \%NUE by roots. It was very low comparing to $\%$ NUE by straw. The best $\%$ NUE by grains was occurred with combined treatment of W1 $\mathrm{x}$ N1 x S3 achieving 67\%. It seems the fertilizer-N was more efficiently used by grains followed by straw while roots recorded the lowest \%NUE. In conclusion, growth and nitrogen fertilizer uptake by barley plants were, in general, enhanced by $\mathrm{N} 1\left(187.2 \mathrm{~kg} \mathrm{~N} \mathrm{ha}^{-1}\right)$ rate applied in splitting doses S3 $(50,25,25)$ under $100 \%$ Etc water regime (W1). 


\section{Introduction}

Irrigation management is one of the most important factors affecting spring barley yield and quality. Drought at any growth stage before grain soft dough reduces spring barley yields, but drought during tillering or between the boot and flowering stages causes the greatest yield reductions. Proper irrigation scheduling matches water applications to crop requirements in a timely and efficient manner (Robertson and Stark). They added that scheduling requires knowledge of crop water use rates and plantavailable soil moisture. Available soil moisture, in turn, depends on soil waterholding capacities and effective rooting depth.

Nutrient management is extremely important in satisfying yield and end-use quality requirements for irrigated spring barley. If inadequate nutrient levels are present, barley yield and end-use quality deteriorate. On the other hand, excessive nitrogen (N) levels can reduce barley grain yield and quality, causing significant economic loss if contract specifications are not met. Excessive plant tissue $\mathrm{N}$ concentrations tend to promote vegetative growth, which increases the potential for foliar diseases and promotes lodging by decreasing straw strength. Excessive soil $\mathrm{N}$ also increases the potential for environmental degradation from nitrate leaching. Proper nutrient management, therefore, is essential for both the grower and the community (Stark and Brown 2003).

They revealed that Nitrogen generally has a greater impact on barley yield and quality than any other nutrient. Four factors that should be considered in making accurate $\mathrm{N}$ fertilizer recommendations are (1) levels of residual inorganic soil $\mathrm{N},(2)$ mineralizable $\mathrm{N}$, (3) previous crop residues, and (4) realistic yield estimates.
On medium-textured loam and silt loam soils a single preplant $\mathrm{N}$ application should be adequate for maximum yield and quality. Sandy, coarse-textured soils require more careful $\mathrm{N}$ and water management because of greater susceptibility to $\mathrm{N}$ leaching. To increase $\mathrm{N}$ efficiency on sandy soils, a split application of $\mathrm{N}$ is advisable. Consider applying 60 percent of the total $\mathrm{N}$ per plant incorporated and the remaining $\mathrm{N}$ during the growing season in two increments, once at tillering (possibly combined with a pesticide) and once at heading. Barley should not be fertilized with $\mathrm{N}$ after tillering to avoid excessive grain protein (Stark and Brown 2003).

In addition, Miao et al., (2015) reviewed that nitrogen $(\mathrm{N})$ deficiency exists in soils worldwide and such deficiency is more serious in dry land areas where crop production solely depends on limited precipitation and where soil fertility is substantially low (Li and Wang, 2006). Consequently, chemical $\mathrm{N}$ fertilization has been extensively used all over the world, and its use has dramatically increased in dryland areas of China. Application of $\mathrm{N}$ fertilizer has played a powerful role in promotion of crop production, especially for three major cereal crops, wheat, maize (Zea mays) and rice (Oryza sativa), which respond intensively to $\mathrm{N}$ fertilizer and can get more benefits from fertilizer $\mathrm{N}$ than other crops (Li et al., 2009).

The input rate of chemical fertilizer $\mathrm{N}$ has remarkably surpassed crop needs (Ju et al., 2009), and therefore $\mathrm{N}$ recovery rate becomes very low, generally in the range of 15-44\% (Ni et al., 2013; Pan et al., 2009). As a result, large amounts of fertilizer $\mathrm{N}$ have been left in soil profile (Wei et al., 2010; Wang et al., 2006; Tong et al., 2005). Under high rainfall precipitation, the accumulated nitrate $\mathrm{N}$ has great risk for 
leaching (Wang et al., 2007; Gao et al., 2005; Yang and Zhang, 2006; Dang et al., 2009), and shallow ground water has been polluted by $\mathrm{NO}_{3}{ }^{-}$in some places of the Loess Plateau (Fan et al., 2005). Liu et al. (1998) reported that $\mathrm{NO}_{3}{ }^{-} \mathrm{N}$ concentrations exceeding $11 \mathrm{mg} \mathrm{N} \mathrm{L}^{-1}$ were found in $20 \%$ of surface water and ground water samples in the Loess Plateau. For solving these problems, maintenance of suitable levels of nitrate $\mathrm{N}$ in soil has been proposed (Liu et al., 2002; Cui et al., 2007). Although difficult to determine the suitable level, reduction of nitrate $\mathrm{N}$ accumulation in soil is absolutely necessary. Basically, there are two ways to do so: by including catch or cover crops to utilize the residual nitrate $\mathrm{N}$, and by not applying excess $\mathrm{N}$ fertilizer to avoid its accumulation. The residual $\mathrm{N}$ is a useful nutrient resource for crop plants (Liu et al., 2002), and that left in soil after summer fallow provides a foundation to meet the $\mathrm{N}$ requirement of wheat, the following crop, at early growing stages, and thus creates a high yield basis (Pen et al., 1981). It is reported that the residual nitrate $\mathrm{N}$ in soil was correlated with crop yield (Ferguson et al., 2002; Fan et al., 2003), and $30-52 \%$ of the residual nitrate $\mathrm{N}$ left in soil by summer maize could be taken up by wheat (Cui et al., 2007).

If input of $\mathrm{N}$ fertilizer is not enough, it is impossible to obtain a high crop yield. In contrast, if input is excessive, the crop will not be able to fully use it, and this will result in low $\mathrm{N}$ recovery and environmental issues. Ideally, the rate of $\mathrm{N}$ fertilizer applied should ensure high yield while leaving no residual $\mathrm{N}$ in the soil after harvest of the crop. For reaching such a purpose, application of $\mathrm{N}$ fertilizer based on soil $\mathrm{N}$ supplying capacity is the fundamental principle (Miao et al., 2015).

The data set constructed by Hall et al.
(2014) was well suited to testing the hypothesis that the responsiveness of wheat and barley development to $\mathrm{N}$ fertilization might be related to the magnitude of $\mathrm{N}$ stress in the unfertilized plots. The range of yields in the unfertilized controls was very broad and responsiveness to fertilization varied widely across experiments and treatments from negligible to three-fold. This implies that the controls in the various experiments included in the dataset effectively explored conditions from no soil $\mathrm{N}$ stress through moderate to extremely severe stress. Within the extremely wide range of yield responsiveness to $\mathrm{N}$, negative responses to yield occurred only exceptionally. It is likely these negative responses were due to haying-off (a negative yield response to $\mathrm{N}$ fertilizer in which vigorous vegetative growth leading to enhanced consumption of water early in the season is followed by terminal drought resulting in pinched grains (see Van Herwanarden et al. (1998) and references therein). They added that it is worth noting that their appraisal revealed that yield responsiveness to $\mathrm{N}$ fertilization in barley was at least similar to that of wheat. This observation conflicts with the belief, generalized in the Mediterranean region, that barley is more adapted to marginal areas (Ryan et al., 2008) and that its yield responds to fertilization less and more erratically than that of wheat. On the other hand, the similarity in responsiveness of barley and wheat found in the current analysis is consistent with the results of recent comparative studies of the two cereals across different water by $\mathrm{N}$ treatments in Mediterranean Spain (Cossani et al., 2007, 2009).

It seems clear that the lack of clear effects of $\mathrm{N}$ fertilization on time-to-flowering in wheat and barley also reflects the fact that its components were also insensitive to $\mathrm{N}$ or exhibit very small responses in opposite 
directions. In a recently published paper reporting the development of floret primordia in durum wheat it was clear that $\mathrm{N}$ fertilization did not affect the rate of development, nor the timing of pollination, of the florets which became fertile in any of the four cultivars analyzed (Ferrante et al., 2013). This finding is consistent with the notion that $\mathrm{N}$ can hardly affect time to flowering if the developmental patterns of the florets which become fertile, and whose pollination mark the flowering stage, are rather insensitive to $\mathrm{N}$.

The objective of this work is to identify the suitable and proper strategy that provide theoretically and technically a quantified basis for applicable irrigation, nitrogen fertilization practices that achieve the optimum barley yield in relation to environmental issues.

\section{Materials and Methods}

\section{Site Description and Experimental Data}

A lysimeter study was conducted at the experimental farm of Soil and Water Research Department, Nuclear Research Center, Atomic Energy Authority, AbouZaabl, Great Cairo, during the winter season 2013/2014. A lysimeter with $37 \mathrm{~cm}$ diameter and $70 \mathrm{~cm}$ height was used as an experimental unit. Every lysimeter was backed with $90 \mathrm{~kg}$ of experimental sand soil. Lysimeter has a hole in the bottom connected with plastic vial for leachat collection. The soil of the experimental work can be classified as sand texture. Some chemical and physical properties are presented in Table (1).

\section{Irrigation Treatments}

A drip irrigation system with emitter discharge at a rate of $41 \mathrm{~h}^{-1}$ was installed.
Three irrigation regimes: 60\%, $80 \%$ and $100 \%$ of crop evapotranspiration (ETc) were investigated during the growth periods of barley crop under greenhouse cultivation. The amounts of irrigation water to be applied for irrigation treatments were measured as traditionally applied in the experiment lysimeter; according to plant observation and growth development stages. Irrigation water was applied for a period of 30 min every five days during the first growth period which was elongated for two weeks. During the second growth period, the time of water application was increased up to 45-60 min every five days for a period of one month, and the time of water application reached up to $80-100$ min every five days for a period of two months. The amount of irrigation water to be applied for the crop evapotranspiration treatment (ET) was estimated using modified FAO PenmanMonteith method. The estimated amounts of water requirement for barley irrigation are presented in Table (2).

\section{Seeds Cultivation and Fertilization Treatments}

Barley (Hordeum vulgare L.), Giza 126 variety, grains were planted at a rate of 20 grain per lysimetr $(0.111$ surface square meters) on 14 February 2014. All treatments received the recommended amounts of phosphorus and potassium fertilizers.

Labeled nitrogen fertilizer in the form of ammonium sulfate enriched with $2 \%$ atom excess was applied at rates of $80 \%(\mathrm{~N} 3)$ (equal to $124.8 \mathrm{~kg} \mathrm{~N} \mathrm{ha}^{-1}$ or $7 \mathrm{~g} \mathrm{~N} \mathrm{lys}^{-1}$ ), $100 \%$ (N2) (equal to $156 \mathrm{~kg} \mathrm{~N}^{-1}$ or $8.76 \mathrm{~g}$ $\mathrm{N}^{1 \mathrm{ys}^{-1}}$ ) and $120 \%$ (N1) (equal to $187.2 \mathrm{~kg} \mathrm{~N}$ $\mathrm{ha}^{-1}$ or $\left.10.51 \mathrm{~g} \mathrm{~N} \mathrm{lys}^{-1}\right)$ of the recommended rate $\left(156 \mathrm{~kg} \mathrm{~N} \mathrm{ha}^{-1}\right)$. Nitrogen fertilizer rates were splitted into three modes of application as following: 
1. $33,33,33 \%(\mathrm{~S} 1)$

2. $40,30,30 \%(\mathrm{~S} 2)$

3. $50,25,25 \%(\mathrm{~S} 3)$

All fertilization treatments were applied at different plant growth periods. All experimental treatments were replicated three times. The experimental units consists of 3 nitrogen fertilizer rates $x 3$ mode of application (splitting) x 3 irrigation water regime $x \quad 3$ replicates which equals 81 lysimeters. The next Table (3) demonstrated the application quantities of nitrogen fertilizer along the plant growth stages.

After harvest, straw, roots and grains were separated and weighed to obtain straw, root and grain dry weight after dryingat $65{ }^{\circ} \mathrm{C}$ for $48 \mathrm{hrs}$ to constant weight. Different plant parts were subjected to wet digestion for determination of total nitrogen content. Nitrogen content in soil was determined accord ing to Carter and Gregorich (2008), while $\mathrm{N}$ content in plant organs as well as available $\mathrm{N}$ forms in leachate were determined according to Temminghoff and Houba (2004).

${ }^{14} \mathrm{~N} /{ }^{15} \mathrm{~N}$ ratio analysis was carried out using emission spectrometer analyzer model Fischer NOI-6PC following the description of IAEA (2001). Distinguish between the different sources of nitrogen gained by different plant parts, i.e. Ndff, \%NUE, Fertilizer-N remained in soil, and fertilizer $\mathrm{N}$ balance was estimated using the following equations:
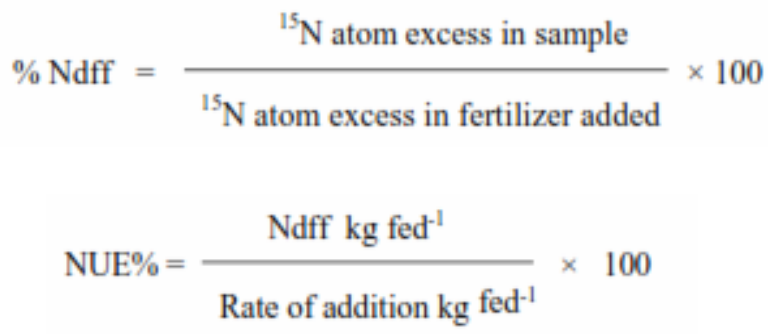

\author{
${ }^{15} \mathrm{~N} \%$ a.e. in soil \\ \%Fertilizer-N remained in soil = ------------- x 100 \\ ${ }^{15} \mathrm{~N} \%$ a.e. in fertilizer added
}

\section{Statistical Analysis}

The effects of three irrigation regimes and three nitrogen rates along with splitting doses regime on yield, growth parameters and water use efficiency of barley crop cultivated in greenhouse were analyzed using a randomized complete block design, using four treatments with three replicates per each treatment. Collected data in this study were analyzed and examined statistically using analysis of variance (ANOVA) from the Statistical Analysis System (SPSS) appropriate for a randomized complete block design (SAS software 2002). Means were compared by LSD test at $5 \%$ level of significance. The mean values of each treatment were designated by letters ( $a$, b, c) which represent the significance degree of the difference between the means. Means represented by two letters in common indicate that the difference is nonsignificant or weakly significant.

\section{Results and Discussion}

\section{Dry Matter Yield}

Dry matter yield of straw was significantly affected by fertilization practices and water regime (Table 4). It seems that straw yield higher with $\mathrm{N} 2\left(191.0 \mathrm{~g} \mathrm{lys}^{-1}\right)$ rate than those of N1 (170.0 g lys ${ }^{-1}$ ) and N3 (123.6 $\left.\mathrm{g} \mathrm{lys}^{-1}\right)$ rates when $\mathrm{W} 1$ regime was applied. Concerning the mode of $\mathrm{N}$ application, the best significant straw yield was achieved with mode $\mathrm{S} 2$. Interaction between fertilizer rates (N2) $x$ mode of application (S2) resulted in the highest value $\left(205.0 \mathrm{~g} \mathrm{lys}^{-1}\right)$ straw yield.

Plants irrigated using $\mathrm{W} 2$ regime in combination with different $\mathrm{N}$ rates and 
application mode resulted in frequent values of straw yield. The highest straw yield was occurred with $\mathrm{W} 2$ interacted with $\mathrm{N} 2$ rate applied with $\mathrm{S} 1$ mode (178 $\left.\mathrm{g} \mathrm{Lys}^{-1}\right)$. The overall means of straw yield as affected by nitrogen rates indicated the superiority of $\mathrm{N} 1$ and $\mathrm{N} 2$ over $\mathrm{N} 3$ but there was no significant difference between them. Straw yield was significantly affected by $\mathrm{N}$ application mode where S1 (152.6) induced the highest value comparable to those of S2 and S3 modes. With $\mathrm{W} 3$ regime, nitrogen fertilizer rate $\mathrm{N} 1$ applied with S3 mode resulted in higher straw yield (183.3) than those recorded with S1 and S2 modes. Comparison between N application modes, on overall mean base, showed that straw yield could be arranged in descending rank: S3 $\square \mathrm{S} 1 \square \mathrm{S} 2$.

In conclusion, straw yield was enhanced by of nitrogen fertilizer at N2 rate applied with S1 or S3. In addition, plants irrigated with W1 followed by W3 water regimes achieved the remarkable values of straw yield.

Root dry weight doesn't reflected significant difference as affected by nitrogen application modes (Table 5). This holds true under all water regimes when grand means were considered. Plants fertilized with either $\mathrm{N} 1$ or N2 induced higher root yield than those obtained with $\mathrm{N} 3$ rate applied in combination with different water regimes. Despite of $\mathrm{N}$ fertilizer rates, root yield of plants irrigated with $\mathrm{W} 1$ regime have the highest significant value among the different irrigation water regimes. It seems that root dry weight mainly significantly positively affected by irrigation water regimes and $\mathrm{N}$ fertilizer rates but not by mode of application.

Effect of water regime, nitrogen fertilizer rates and application modes on grain yield (Table 6) indicated the superiority of $\mathrm{N} 2$ rate applied with S2 mode over other treatments where the grain yield accounted for $76.40 \mathrm{~g}$ lys $^{-1}$ followed by those resulted from interaction between $\mathrm{W} 1 \times \mathrm{N} 3$ using $\mathrm{S} 1$ application mode $\left(74.11 \mathrm{~g} \mathrm{lys}^{-1}\right)$. Mean average showed a little bit, but not significant, difference between modes of $\mathrm{N}$ application. On the other hand, N3 rate gave, to somewhat extent, high grain yield as compared to other $\mathrm{N}$ fertilization rates. Interaction between $\mathrm{W} 1$ regime, $\mathrm{N}$ rates under different application modes resulted in an average of grain yield accounted for $67.06 \mathrm{~g} \mathrm{lys}^{-1}$.

Another view was observed with W2 whereas S3 mode pointed out higher mean average (68.35 $\mathrm{g} \mathrm{lys}^{-1}$ ) of grain yield than those of $\mathrm{S} 1$ and $\mathrm{S} 2$ modes. In this respect, there was no significant difference between $\mathrm{S} 1$ and $\mathrm{S} 2$ modes. Irrigation with $\mathrm{W} 2$ regime combined with either $\mathrm{N} 2$ or N3 fertilizer rates applied at $\mathrm{S} 3$ splitting doses resulted in higher grain yield than other treatments. Similar trend, but to somewhat low extent, was noticed with W3 regime. The overall mean confirmed the superiority of W1 followed by W2 but the difference between them was not so high. In addition, nitrogen fertilizer added at rate N2 with S3 mode of application induced the best values of grain yield. With W3, the plants seem to be suffered from water shortage (deficit water condition) which reflected the lowest grain yield among the tested treatments. From the economical view point, W2 combined with $\mathrm{N} 2$ rate, despite of mode of application, could be considered the best one scenario applied under experimental given conditions.

\section{Nitrogen Uptake}

Nitrogen uptake by barley straw tended to increase with application of $\mathrm{N} 2$ rate splitted into $50,25,25$ (S3) doses as compared to other rates $\mathrm{x}$ mode of application (Table 7). Reducing irrigation water $(80 \%)$ regime declines $\mathrm{N}$ uptake by barely straw. This 
holds true with all nitrogen rates especially those applied with S2 and S3 modes. It is surprise that application of W3 (60\%) regime reflected straw-N uptake higher than those recorded with W2 but nearly closed to those of $\mathrm{W} 1$ regime. This may give us the chance to recommend, with special emphasis on cost of irrigation water, this regime in combination with $\mathrm{N} 2$ fertilizer rate as best scenario for achieving remarkable nitrogen uptake by barley plants. Mode of $\mathrm{N}$ application S1 (33, 33, 33) also be considered, in general, as better splitting doses than other splitting modes.

Nitrogen uptake by roots (Table 8), showed fluctuated pattern as affected by fertilizer rates, splitting doses in combination with irrigation water regime. Application of N1 or N2 using splitting mode S1or S2 resulted in higher $\mathrm{N}$ uptake by roots than $\mathrm{N} 3$ rate added using S3 mode when 100\% (W1) water regime was considered. Reversibly, W2 $(80 \%)$ regime combined with N1 rate applied with S3 mode induced the best value of $\mathrm{N}$ uptake by roots. In this respect, the overall means indicated superiority of $\mathrm{N} 1$ rate and splitting mode $\mathrm{S} 3$ where $\mathrm{N}$ uptake gradually decreased with $\mathrm{N} 2$ and $\mathrm{N} 3$ rates.

Under W3 water regime, plants fertilized with $\mathrm{N} 2$ rate reflects higher $\mathrm{N}$ uptake by roots when S1application mode (0.28).

In conclusion, the overall means of $\mathrm{N}$ uptake by roots showed superiority of $\mathrm{N} 2$ under $\mathrm{W} 1$ and W3 while N1 was the best under W2 regime. Comparison between water regimes leads to superiority of W1 followed by W3 then W2. Concerning the fertilizer splitting modes, the grand mean of $\mathrm{N}$ uptake by roots was the best when S1 was used followed by $\mathrm{S} 3$ then $\mathrm{S} 2$.

Nitrogen uptake by grains was the best (1.49) when plants were fertilized with N1 rate added using splitting mode S3 under W1 regime (Table 9). Despite of splitting modes, the overall means of $\mathrm{N}$ uptake by grains showed the superiority of N1 over N2 and N3 fertilizer rates, respectively. Also, means of splitting mode indicated that S1 was superior over S2 and S3, respectively. A little bit differences were noticed with W2 regime where the overall means of $\mathrm{N}$ rates indicated that $\mathrm{N} 2$ rate was the best among others. In the same time, S3 andS1 were superior over $\mathrm{S} 2$ as indicated by overall mean of splitting modes. Similar trends, but with some exceptions, were noticed with application of $\mathrm{W} 3$ water regime.

Water regime W1 interacted with either N1 or $\mathrm{N} 2$ achieved the best values of $\mathrm{N}$ uptake by grains. The grand mean of $\mathrm{N}$ uptake by grains as affected by application modes pointed out no big significant difference between them.

\section{Nitrogen Derived from Fertilizer (NDFF)}

The portion and absolute values of nitrogen derived from fertilizer (Table 10), by straw were significantly affected by water regime and fertilizer rates applied at different splitting modes. Plants irrigated using W1 regime derived higher quantities of $\mathrm{N}$ from $\mathrm{N} 1$ and N2 rates applied with splitting mode S3 than those recorded with N3 rate. Similar trend, but with $\mathrm{S} 1$ mode, was observed under W2 water regime. It seems that Ndff by straw was to somewhat extent lower than those of $\mathrm{W} 1$ water regime. Under $\mathrm{W} 3$, the portions and absolute values of Ndff by straw were nearly closed to those recorded with W1. Generally, percentages of N derived from fertilizer don't exceed $29 \%$ from the total $\mathrm{N}$ uptake by straw. There are no clear cut evident between water regimes when Ndff absolute values was considered.

Nitrogen derived from fertilizer by roots, 
generally, was very low (Table 11). The obtained data didn't reflect any significant differences between the tested parameters.

Table (12), showed that the percent Ndff by grains was near to $32 \%$ that reflects the highest value achieved by application N1 rate using splitting mode $\mathrm{S} 3$ when $\mathrm{W} 1$ water regime was concerned. Application of N3 rate with $\mathrm{S} 2(0.40)$ came to the next. It seems that S2 and S3 modes were nearly closed to each other. In this respect, absolute values of Ndff by grains, as mean, were not significantly varied according to different fertilizer $\mathrm{N}$ rates. W2 water regime showed, to some extent, lower quantities of Ndff by straw than those recorded with $\mathrm{W} 1$ regime but slightly higher than those of $\mathrm{W} 3$ water regime. Combined treatment of $\mathrm{W} 1 \mathrm{xN} 2 \mathrm{xS} 3$ was the best where it gave the remarkable Ndff values as indicated by overall means of the tested factors.

\section{Nitrogen use Efficiency (\% NUE)}

Efficient use of mineral $\mathrm{N}$ fertilizer by different plant organs was significantly positively or negatively affected by water regime, $\mathrm{N}$ rates and mode of application (Table 13). Nitrogen used by straw was more efficient with $\mathrm{N} 1$ rate applied with $\mathrm{S} 3$ mode under $\mathrm{W} 1$ irrigation regime (51\%), followed by $\mathrm{N} 2$ then $\mathrm{N} 3$ rate. It seems that $\%$ NUE was decreased with decreasing $\mathrm{N}$ fertilizer rates. Under $\mathrm{W} 2$ regime, the high $\%$ NUE was detected with $\mathrm{N} 1$ rate $(53 \%)$ applied with S1 mode. In this respect, the mean of splitting modes showed the following ranking: S1 $\square$ S3 $\square$ S2. Means of nitrogen application rates reflected the superiority of $\mathrm{N} 1$ rate over $\mathrm{N} 2$ then $\mathrm{N} 3$. W3 regime interacted with $\mathrm{N} 1$ rate applied with either $\mathrm{S} 1$ or $\mathrm{S} 3$ resulted in higher \%NUE by straw than $\mathrm{N} 2$ and $\mathrm{N} 3$ applied with $\mathrm{S} 2$ splitting mode. Concerning irrigation water regime, the best \%NUE by straw was detected with W1 (34\%) =W3 (34\%) and higher than $\mathrm{W} 2$ regime $(29.5 \%)$.

Generally, \%NUE by straw of plants fertilized with $\mathrm{N} 1\left(187.2 \mathrm{~kg} \mathrm{~N} \mathrm{ha}^{-1}\right)$ rate surpass that of $\mathrm{N} 2\left(156 \mathrm{~kg} \mathrm{~N} \mathrm{ha}^{-1}\right)$ and N3 (124.8 $\left.\mathrm{kg} \mathrm{N} \mathrm{ha}^{-1}\right)$, rates. This holds true different water regimes. Efficient use of $\mathrm{N}$ fertilizer as affected by water regime was equal in $\mathrm{W} 1$ and $\mathrm{W} 3(34.1 \%)$ and both were higher than W2 regime. Splitting dose mode superiority was dependent on water regime whereas \%NUE of straw enhanced by S3 under $\mathrm{W} 1$ and $\mathrm{W} 3$ regimes while it was lower with W2 regime.

In case of roots, \%NUE followed the same trend with some exceptions related to splitting modes where S1 was better than S2 and S3 with W1and W3 while S3 was better than both with W2 regime. Efficient use of fertilizer nitrogen by roots was very low comparing to those of straw.

Grains seem to be more effective in using fertilizer-N where \%NUE were significantly higher than those recorded with straw and/or roots. The effect of $\mathrm{N}$ rates on $\% \mathrm{NUE}$ could be ranked as following: N1 N2 N3. Similar trend was noticed with water regimes where $\mathrm{W} 1$ was superior over W2 then W3 regime. Effect of splitting modes was fluctuated in relation to water regimes. In this respect, S2 was the best under W1 while S3 was the best under $\mathrm{W} 2$ and $\mathrm{W} 3$ water regimes.

Based on scientific background, nutrient input is the key for crop production. Consequently, roots are essential for taking up water and nutrients to support crop growth, and the significance of roots becomes even more important on drylands, since the topsoil is often dry and nutrients are often unavailable, and plants need to extend their roots into deep layer to obtain available nutrients in the moist soil. It has 
been found that in most cases, crop yield is highly correlated with crop root mass almost in a linear shape (Li et al., 2009). In this regard, the management of fertilizer nitrogen application rates or splitting modes could be beneficiary as reduction in $\mathrm{N}$ rates without reducing the crop yield put into consideration (Hartman et al., 2015).

Dry matter yield of barley straw, roots and grain yield were significantly higher with W1 and W2 in combination with moderate rate $(\mathrm{N} 2)$ of fertilizer nitrogen despite of splitting modes. On line with us, Li-min et al., (2015) found that across all years, grain yield (GY) and dry matter of irrigated wheat grown in lysimeter under W1 $(500 \mathrm{~mm})$ irrigation were significantly higher than under W2 $(350 \mathrm{~mm})$ irrigation. Under W1 irrigation, they recorded that GY was much higher with higher rates of $\mathrm{N}$ application $\left(180 \mathrm{~kg} \mathrm{ha}^{-1}\right)$ either as manure or urea (i.e., the M1 and $\mathrm{U} 1$ treatments), but the $\mathrm{N}$ application rate (180 or $\left.90 \mathrm{~kg} \mathrm{~N} \mathrm{ha}^{-1}\right)$ had no effect under W2 irrigation.

Table.1 Some Physical and Chemical Properties of Experimental Soil

\begin{tabular}{|c|c|}
\hline Property & Value \\
\hline \multicolumn{2}{|c|}{ Particle size distribution \% } \\
\hline Sand & 91.5 \\
\hline Silt & 2.7 \\
\hline Clay & 5.8 \\
\hline Texture class & Sand \\
\hline Bulk density & 1.75 \\
\hline Organic matter $\%$ & 0.43 \\
\hline $\mathrm{CaCO}_{3} \%$ & 1.21 \\
\hline $\mathrm{pH}(1: 2.5)$ & 7.8 \\
\hline $\operatorname{EC~}(1: 5) \mathrm{dS} \mathrm{m}^{-1}$ & 0.65 \\
\hline \multicolumn{2}{|c|}{ Available nutrients (meq $100 \mathrm{~g}^{-1}$ ) } \\
\hline $\mathrm{N}$ & 0.01 \\
\hline $\mathrm{P}$ & 0.20 \\
\hline \multicolumn{2}{|l|}{ Cations (meq $100 \mathrm{~g}^{-1}$ soil) } \\
\hline $\mathrm{Na}^{+}$ & 0.2 \\
\hline $\mathrm{K}^{+}$ & 0.09 \\
\hline $\mathrm{Ca}^{++}$ & 1.45 \\
\hline $\mathrm{Mg}^{++}$ & 1.18 \\
\hline \multicolumn{2}{|l|}{ Anions (meq $100 \mathrm{~g}^{-1}$ soil) } \\
\hline $\mathrm{Cl}^{-}$ & 0.66 \\
\hline $\mathrm{HCO}_{3}{ }^{-}$ & 1.9 \\
\hline $\mathrm{CO}_{3}^{-}$ & 0.00 \\
\hline $\mathrm{SO}_{4}^{-}$ & 0.36 \\
\hline
\end{tabular}


Table.2 Amounts of Irrigation Water Added (mm) Throughout Barley Growth Season According to FAO (33)

\begin{tabular}{|c|c|c|c|c|c|c|c|}
\hline \multicolumn{2}{|c|}{ Duration } & $\begin{array}{c}\text { Irrigation } \\
\text { Interval } \\
\text { (days) }\end{array}$ & $\begin{array}{c}\text { Crop } \\
\text { Growth } \\
\text { (stage) }\end{array}$ & $\begin{array}{c}\text { Crop } \\
\text { coefficient }\end{array}$ & $\begin{array}{r}60 \% \\
\text { I.W.A } \\
(\mathrm{mm}) \\
\end{array}$ & $\begin{array}{r}80 \% \\
\text { I.W.A } \\
(\mathrm{mm}) \\
\end{array}$ & $\begin{array}{l}100 \% \\
\text { I.W.A } \\
(\mathrm{mm}) \\
\end{array}$ \\
\hline $\begin{array}{l}19 / 12 \\
3 / 1\end{array}$ & - & 5 & $\begin{array}{c}\text { Initial } \\
\text { (20) days }\end{array}$ & 0.4 & 5.36 & 7.15 & 8.94 \\
\hline $\begin{array}{l}8 / 1 \\
22 / 2\end{array}$ & - & 5 & $\begin{array}{l}\text { Development } \\
\text { (50) days }\end{array}$ & 0.8 & 10.73 & 14.30 & 17.88 \\
\hline $\begin{array}{l}27 / 2 \\
8 / 4\end{array}$ & - & 5 & $\begin{array}{l}\text { Mid-season } \\
\text { (45) days }\end{array}$ & 1.2 & 16.09 & 21.46 & 26.83 \\
\hline $\begin{array}{l}13 / 4 \\
8 / 5 \\
\end{array}$ & - & 5 & $\begin{array}{c}\text { Late-season } \\
\text { (30) days }\end{array}$ & 0.7 & 9.39 & 12.52 & 15.65 \\
\hline \multicolumn{5}{|c|}{ Total water (mm / season) } & 330 & 440 & 550 \\
\hline
\end{tabular}

Table.3 Nitrogen Fertilizer Rates in Gm Lys-1 at Different Periods

\begin{tabular}{|c|c|c|c|c|c|c|c|c|c|c|}
\hline \multirow{2}{*}{$\mathbf{N}$ rate } & \multicolumn{3}{|c|}{$50 \%$} & \multicolumn{3}{|c|}{$40 \%$} & \multirow{2}{*}{\multicolumn{3}{|c|}{$33 \%$}} & \multirow{2}{*}{ Total } \\
\hline & \multicolumn{6}{|c|}{$\operatorname{kg~N~Fed~}^{-1}$} & & & & \\
\hline $\mathrm{kg} \mathrm{fed}^{-1}$ & 52 & 65 & 78 & 52 & 65 & 78 & 52 & 65 & 78 & \\
\hline Per Lys & 3.50 & 4.38 & 5.25 & 2.80 & 3.50 & 4.20 & 2.35 & 2.92 & 3.5 & \\
\hline 9 Lys & 31.5 & 39.4 & 47.3 & 25.2 & 31.5 & 37.8 & 21.2 & 26.3 & 31.5 & 292 gm \\
\hline \multicolumn{11}{|c|}{ A- At day 40 after sowing } \\
\hline \multirow{2}{*}{$\mathrm{N}$ rate } & \multicolumn{3}{|c|}{$25 \%$} & \multicolumn{3}{|c|}{$30 \%$} & \multirow{2}{*}{\multicolumn{3}{|c|}{$33 \%$}} & \multirow{2}{*}{ Total } \\
\hline & \multicolumn{6}{|c|}{$\operatorname{kg~N~Fed~}^{-1}$} & & & & \\
\hline $\mathrm{kg} \mathrm{fed}^{-1}$ & 52 & 65 & 78 & 52 & 65 & 78 & 52 & 65 & 78 & \\
\hline Per Lys & 1.75 & 2.19 & 2.63 & 2.10 & 2.63 & 315 & 2.35 & 2.92 & 3.5 & \\
\hline 9 Lys & 15.8 & 19.7 & 23.7 & 18.9 & 23.7 & 28.4 & 21.2 & 26.3 & 31.5 & $210 \mathrm{gm}$ \\
\hline \multirow{2}{*}{ N rate } & \multicolumn{3}{|c|}{$25 \%$} & \multicolumn{3}{|c|}{$30 \%$} & \multirow{2}{*}{\multicolumn{3}{|c|}{$33 \%$}} & \multirow{2}{*}{ Total } \\
\hline & \multicolumn{6}{|c|}{$\operatorname{kg~N~Fed~}^{-1}$} & & & & \\
\hline $\mathrm{kg} \mathrm{fed}^{-1}$ & 52 & 65 & 78 & 52 & 65 & 78 & 52 & 65 & 78 & \\
\hline Per Lys & 1.75 & 2.19 & 2.63 & 2.10 & 2.63 & 315 & 2.35 & 2.92 & 3.5 & \\
\hline 9 Lys & 15.8 & 19.7 & 23.7 & 18.9 & 23.7 & 28.4 & 21.2 & 26.3 & 31.5 & $210 \mathrm{gm}$ \\
\hline
\end{tabular}


Table.4 Effect of N Fertilizer Rates, Splitting Doses and Water Regime on Straw Yield (g Lys.-1) of Barley Plants

\begin{tabular}{|c|c|c|c|c|c|}
\hline \multirow{2}{*}{$\begin{array}{c}\text { Water } \\
\text { regime* }^{*}\end{array}$} & \multirow{2}{*}{$\begin{array}{c}\text { N-fertilizer } \\
\text { rate* }^{*}\end{array}$} & \multicolumn{3}{|c|}{ Splitting doses* } & \multirow{2}{*}{ mean } \\
\hline & & $\mathbf{S}_{1}$ & $\mathbf{S}_{2}$ & $\mathbf{S}_{\mathbf{3}}$ & \\
\hline \multirow{4}{*}{$\begin{array}{c}\mathbf{W}_{1} \\
(100 \% \\
\text { Etc })\end{array}$} & $\mathbf{N}_{1}$ & $135.0 \mathrm{fg}$ & $198.0 \mathrm{ab}$ & $177.0 \mathrm{~cd}$ & 170.0 \\
\hline & $\mathbf{N}_{2}$ & $185.7 \mathrm{bc}$ & 205.0 a & $182.3 \mathrm{bc}$ & 191.0 \\
\hline & $\mathbf{N}_{3}$ & $120.0 \mathrm{hi}$ & $119.7 \mathrm{hi}$ & $131.0 \mathrm{fg}$ & 123.6 \\
\hline & Mean & 146.9 & 174.2 & 163.4 & 161.5 \\
\hline \multirow{4}{*}{$\begin{array}{c}W_{2} \\
(80 \% \text { Etc })\end{array}$} & $\mathbf{N}_{1}$ & $160.7 \mathrm{de}$ & $123.0 \mathrm{~h}$ & $115.0 \mathrm{i}$ & 133.1 \\
\hline & $\mathbf{N}_{2}$ & $178.0 \mathrm{c}$ & $108.0 \mathrm{k}$ & $116.3 \mathrm{i}$ & 134.1 \\
\hline & $\mathbf{N}_{3}$ & $119.0 \mathrm{hi}$ & $109.0 \mathrm{j}$ & 103.01 & 110.3 \\
\hline & Mean & 152.6 & 113.6 & 111.4 & 125.8 \\
\hline \multirow{5}{*}{$\begin{array}{c}\mathrm{W}_{3} \\
(60 \% \text { Etc })\end{array}$} & $\mathbf{N}_{1}$ & 145.7 ef & $101.7 \mathrm{~m}$ & $183.3 \mathrm{c}$ & 143.6 \\
\hline & $\mathbf{N}_{2}$ & 144.7 ef & 148.0 ef & $142.3 \mathrm{f}$ & 145.0 \\
\hline & $\mathbf{N}_{3}$ & 103.31 & $126.0 \mathrm{gh}$ & $101.7 \mathrm{~m}$ & 110.3 \\
\hline & Mean & 131.2 & 125.2 & 142.4 & 132.9 \\
\hline & Grand mean & 143.6 & 104.3 & 139.1 & \\
\hline
\end{tabular}

Means in the same column followed by the same letter are not significantly different at $P \leq 0.05$

*For definition see materials and methods section

Table.5 Effect of N Fertilizer Rates, Splitting Doses and Water Regime (W1, W2 and W3) on Roots Dry Weight (g Lys.-1) of Barley Plants

\begin{tabular}{|c|c|c|c|c|c|}
\hline \multirow{2}{*}{ Water regime } & \multirow{2}{*}{$\begin{array}{c}\mathbf{N} \text { fertilizer } \\
\text { rate }\end{array}$} & \multicolumn{3}{|c|}{ Splitting doses } & \multirow{2}{*}{ mean } \\
\hline & & $\mathbf{S}_{1}$ & $\mathbf{S}_{2}$ & $\mathbf{S}_{\mathbf{3}}$ & \\
\hline \multirow{4}{*}{$\begin{array}{c}W_{1} \\
(100 \% \text { Etc })\end{array}$} & $\overline{\mathbf{N}_{1}}$ & $37.67 \mathrm{a}$ & 38.67 a & $35.33 \mathrm{~b}$ & 37.22 \\
\hline & $\mathbf{N}_{2}$ & $31.00 \mathrm{c}$ & $37.67 \mathbf{a}$ & $35.33 \mathrm{~b}$ & 34.67 \\
\hline & $\mathbf{N}_{3}$ & $24.33 \mathrm{i}$ & $29.67 \mathrm{~cd}$ & $25.00 \mathrm{~h}$ & 26.33 \\
\hline & Mean & 31.00 & 35.33 & 31.89 & 32.74 \\
\hline \multirow{4}{*}{$\begin{array}{c}\mathrm{W}_{2} \\
(80 \% \text { Etc })\end{array}$} & $\mathbf{N}_{1}$ & $26.67 \mathrm{f}$ & $29.00 \mathrm{~cd}$ & $28.67 \mathrm{~d}$ & 28.11 \\
\hline & $\mathbf{N}_{2}$ & $27.00 \mathrm{e}$ & $22.00 \mathrm{j}$ & $22.00 \mathrm{j}$ & 23.67 \\
\hline & $\mathbf{N}_{3}$ & $17.33 \mathrm{kl}$ & 16.331 & $18.00 \mathrm{kl}$ & 17.22 \\
\hline & Mean & 23.67 & 22.44 & 22.89 & 23.00 \\
\hline \multirow{4}{*}{$\begin{array}{c}W_{3} \\
(60 \% \text { Etc })\end{array}$} & $\mathbf{N}_{1}$ & $25.00 \mathrm{~h}$ & $27.00 \mathrm{e}$ & $26.67 \mathrm{f}$ & 26.22 \\
\hline & $\mathbf{N}_{2}$ & $30.00 \mathrm{~cd}$ & $26.00 \mathrm{~g}$ & $24.00 \mathrm{i}$ & 26.67 \\
\hline & $\mathbf{N}_{3}$ & $22.00 \mathrm{j}$ & $19.00 \mathrm{k}$ & $23.67 \mathrm{ij}$ & 21.56 \\
\hline & Mean & 25.67 & 24.00 & 24.78 & 24.81 \\
\hline \multicolumn{2}{|c|}{ Grand mean } & 26.78 & 27.26 & 26.52 & \\
\hline
\end{tabular}

Means in the same column followed by the same letter are not significantly different at $P \leq 0.05$ 
Table.6 Effect of N Fertilizer Rates, Splitting Doses and Water Regime (W1, W2 and W3) on Grain Yield (g Lys.-1) of Barley Plants

\begin{tabular}{|c|c|c|c|c|c|}
\hline \multirow{2}{*}{ Water regime } & \multirow{2}{*}{$\begin{array}{c}\mathbf{N} \text { fertilizer } \\
\text { rate }\end{array}$} & \multicolumn{3}{|c|}{ Splitting doses } & \multirow{2}{*}{ mean } \\
\hline & & $\mathbf{S}_{1}$ & $\mathbf{S}_{2}$ & $\mathbf{S}_{\mathbf{3}}$ & \\
\hline \multirow{4}{*}{$\begin{array}{c}W_{1} \\
(100 \% \text { Etc })\end{array}$} & $\overline{N_{1}}$ & $63.91 \mathrm{~b}$ & $61.63 \mathrm{c}$ & $65.64 \mathrm{ab}$ & 63.73 \\
\hline & $\mathbf{N}_{2}$ & $65.62 \mathrm{ab}$ & $76.40 \mathrm{a}$ & $60.25 \mathrm{c}$ & 67.43 \\
\hline & $\mathbf{N}_{3}$ & $74.11 \mathrm{a}$ & $69.48 \mathrm{ab}$ & $66.51 \mathrm{ab}$ & 70.04 \\
\hline & Mean & 67.88 & 69.17 & 64.13 & 67.06 \\
\hline \multirow{4}{*}{$\begin{array}{c}\mathrm{W}_{2} \\
(80 \% \text { Etc })\end{array}$} & $\overline{\mathbf{N}_{1}}$ & $53.53 \mathrm{f}$ & $42.46 \mathrm{j}$ & $63.81 \mathrm{~b}$ & 54.27 \\
\hline & $\mathbf{N}_{2}$ & $59.73 \mathrm{~d}$ & $67.10 \mathrm{ab}$ & $69.68 \mathrm{ab}$ & 65.51 \\
\hline & $\mathbf{N}_{3}$ & $59.86 \mathrm{~d}$ & $57.89 \mathrm{e}$ & $71.56 \mathrm{ab}$ & 63.11 \\
\hline & Mean & 57.71 & 56.82 & 68.35 & 60.96 \\
\hline \multirow{4}{*}{$\begin{array}{c}W_{3} \\
(60 \% \text { Etc })\end{array}$} & $\overline{N_{1}}$ & 35.77 I & $48.40 \mathrm{~h}$ & $43.08 \mathrm{j}$ & 42.42 \\
\hline & $\mathbf{N}_{2}$ & $49.13 \mathrm{~g}$ & $46.32 \mathrm{j}$ & $52.77 \mathrm{f}$ & 49.41 \\
\hline & $\mathbf{N}_{3}$ & $47.28 \mathrm{i}$ & $43.12 \mathrm{j}$ & $39.63 \mathrm{k}$ & 43.35 \\
\hline & Mean & 44.06 & 45.95 & 45.16 & 45.06 \\
\hline \multicolumn{2}{|c|}{ Grand mean } & 56.55 & 57.31 & 59.21 & \\
\hline
\end{tabular}

Means in the same column followed by the same letter are not significantly different at $P \leq 0.05$

Table.7 Effect of N Fertilizer Rates, Splitting Doses and Water Regime (W1, W2 and W3) on N Uptake by Straw (g Lys.-1) of Barley Plants

\begin{tabular}{|c|c|c|c|c|c|}
\hline \multirow{2}{*}{$\begin{array}{l}\text { Water } \\
\text { regime }\end{array}$} & \multirow{2}{*}{$\mathbf{N}$ fertilizer rate } & \multicolumn{3}{|c|}{ Splitting doses } & \multirow{2}{*}{ Mean } \\
\hline & & $S_{1}$ & $\mathbf{S}_{2}$ & $\mathbf{S}_{3}$ & \\
\hline \multirow{4}{*}{$\begin{array}{l}W_{1} \\
(100 \% \text { Etc })\end{array}$} & $\mathbf{N}_{1}$ & $1.13 \mathrm{c}$ & $1.13 \mathrm{c}$ & $1.25 \mathrm{~b}$ & 1.17 \\
\hline & $\mathbf{N}_{2}$ & $1.39 \mathrm{ab}$ & $0.91 \mathrm{e}$ & $1.42 \mathrm{ab}$ & 1.24 \\
\hline & $\mathbf{N}_{3}$ & $0.75 \mathrm{fg}$ & $0.71 \mathrm{~g}$ & $0.92 \mathrm{e}$ & 0.80 \\
\hline & Mean & 1.09 & 0.92 & 1.20 & 1.07 \\
\hline \multirow{4}{*}{$\begin{array}{l}\mathrm{W}_{2} \\
(80 \% \text { Etc) }\end{array}$} & $\mathbf{N}_{1}$ & $1.58 \mathrm{a}$ & $0.86 \mathrm{f}$ & 0.89 ef & 1.11 \\
\hline & $\mathbf{N}_{2}$ & $1.39 \mathrm{ab}$ & $0.69 \mathrm{gh}$ & $0.74 \mathrm{fg}$ & 0.94 \\
\hline & $\mathbf{N}_{3}$ & $0.70 \mathrm{~g}$ & $0.59 \mathrm{i}$ & $0.67 \mathrm{gh}$ & 0.65 \\
\hline & Mean & 1.22 & 0.71 & 0.77 & 0.90 \\
\hline \multirow{4}{*}{$\begin{array}{l}\mathrm{W}_{3} \\
(60 \% \text { Etc })\end{array}$} & $\mathbf{N}_{1}$ & $1.19 \mathrm{bc}$ & $0.71 \mathrm{~g}$ & $1.32 \mathrm{abc}$ & 1.07 \\
\hline & $\mathbf{N}_{2}$ & $1.39 \mathrm{ab}$ & $1.33 \mathrm{abc}$ & $0.98 \mathrm{~d}$ & 1.23 \\
\hline & $\mathbf{N}_{3}$ & $0.64 \mathrm{~h}$ & $0.84 \mathrm{f}$ & $0.88 \mathrm{ef}$ & 0.79 \\
\hline & Mean & 1.07 & 0.96 & 1.06 & 1.03 \\
\hline \multicolumn{2}{|l|}{ Grand mean } & 1.13 & 0.86 & 1.01 & \\
\hline
\end{tabular}

Means in the same column followed by the same letter are not significantly different at $P \leq 0.05$ 
Table.8 Effect of N Fertilizer Rates, Splitting Doses and Water Regime (W1, W2 and W3) on N Uptake by Roots (g Lys.-1) of Barley Plants

\begin{tabular}{|c|c|c|c|c|c|}
\hline \multirow{2}{*}{ Water regime } & \multirow{2}{*}{$\begin{array}{c}\mathbf{N} \text { fertilizer } \\
\text { rate }\end{array}$} & \multicolumn{3}{|c|}{ Splitting doses } & \multirow{2}{*}{ mean } \\
\hline & & $\mathbf{S}_{1}$ & $\mathbf{S}_{2}$ & $\mathbf{S}_{3}$ & \\
\hline \multirow{4}{*}{$\begin{array}{c}W_{1} \\
(100 \% \text { Etc })\end{array}$} & $\overline{N_{1}}$ & $0.24 \mathrm{ab}$ & $0.18 \mathrm{c}$ & $0.16 \mathrm{~d}$ & 0.20 \\
\hline & $\mathbf{N}_{2}$ & $0.15 \mathrm{e}$ & $0.24 \mathrm{ab}$ & $0.21 \mathrm{~b}$ & 0.20 \\
\hline & $\mathbf{N}_{3}$ & $0.20 \mathrm{~b}$ & $0.14 \mathrm{e}$ & $0.11 \mathrm{~g}$ & 0.15 \\
\hline & Mean & 0.20 & 0.19 & 0.16 & 0.18 \\
\hline \multirow{4}{*}{$\begin{array}{c}\mathrm{W}_{2} \\
(80 \% \text { Etc })\end{array}$} & $\mathbf{N}_{1}$ & $0.17 \mathrm{~d}$ & $0.13 \mathrm{f}$ & $0.23 \mathrm{ab}$ & 0.17 \\
\hline & $\mathbf{N}_{2}$ & $0.14 \mathrm{e}$ & $0.13 \mathrm{f}$ & $0.14 \mathrm{e}$ & 0.14 \\
\hline & $\mathbf{N}_{3}$ & $0.12 \mathrm{f}$ & 0.07 i & $0.11 \mathrm{~g}$ & 0.10 \\
\hline & Mean & 0.14 & 0.11 & 0.16 & 0.14 \\
\hline \multirow{4}{*}{$\begin{array}{c}\mathrm{W}_{3} \\
(60 \% \text { Etc })\end{array}$} & $\overline{N_{1}}$ & $0.17 \mathrm{~d}$ & $0.14 \mathrm{e}$ & $0.15 \mathrm{e}$ & 0.15 \\
\hline & $\mathbf{N}_{2}$ & $0.28 \mathrm{a}$ & $0.16 \mathrm{~d}$ & $0.15 \mathrm{e}$ & 0.19 \\
\hline & $\mathbf{N}_{3}$ & $0.14 \mathrm{e}$ & $0.08 \mathrm{~h}$ & $0.16 \mathrm{~d}$ & 0.13 \\
\hline & Mean & 0.19 & 0.13 & 0.15 & 0.16 \\
\hline \multicolumn{2}{|c|}{ Grand mean } & 0.18 & 0.14 & 0.16 & \\
\hline
\end{tabular}

Means in the same column followed by the same letter are not significantly different at $P \leq 0.05$

Table.9 Effect of N Fertilizer Rates, Splitting Doses and Water Regime (W1, W2 and W3) on N Uptake by Grains (g Lys.-1) of bBarley Plants

\begin{tabular}{|c|c|c|c|c|c|}
\hline \multirow{2}{*}{ Water regime } & \multirow{2}{*}{$\mathbf{N}$ fertilizer rate } & \multicolumn{3}{|c|}{ Splitting doses } & \multirow{2}{*}{ mean } \\
\hline & & $\mathbf{S}_{1}$ & $\mathbf{S}_{2}$ & $\mathbf{S}_{3}$ & \\
\hline \multirow{4}{*}{$\begin{array}{c}W_{1} \\
(100 \% \text { Etc })\end{array}$} & $\mathbf{N}_{1}$ & $1.33 \mathrm{ab}$ & $1.31 \mathrm{ab}$ & $1.49 \mathrm{a}$ & 1.38 \\
\hline & $\mathbf{N}_{2}$ & $1.36 \mathrm{ab}$ & $1.40 \mathrm{a}$ & $1.00 \mathrm{gh}$ & 1.25 \\
\hline & $\mathbf{N}_{3}$ & $1.23 \mathrm{~b}$ & $1.04 \mathrm{f}$ & $0.84 \mathrm{i}$ & 1.03 \\
\hline & Mean & 1.30 & 1.25 & 1.11 & 1.21 \\
\hline \multirow{4}{*}{$\begin{array}{c}\mathrm{W}_{2} \\
(80 \% \text { Etc })\end{array}$} & $\mathbf{N}_{1}$ & $1.25 \mathrm{~b}$ & $0.75 \mathrm{j}$ & $1.28 \mathrm{ab}$ & 1.09 \\
\hline & $\mathbf{N}_{2}$ & $1.25 \mathrm{~b}$ & $1.05 \mathrm{e}$ & $1.24 \mathrm{~b}$ & 1.18 \\
\hline & $\mathbf{N}_{3}$ & $1.01 \mathrm{~g}$ & $0.89 \mathrm{~h}$ & $1.12 \mathrm{c}$ & 1.01 \\
\hline & Mean & 1.17 & 0.90 & 1.21 & 1.09 \\
\hline \multirow{4}{*}{$\begin{array}{c}W_{3} \\
(60 \% \text { Etc })\end{array}$} & $\overline{N_{1}}$ & $0.63 \mathrm{k}$ & $0.93 \mathrm{~h}$ & $1.06 \mathrm{e}$ & 0.87 \\
\hline & $\mathbf{N}_{2}$ & $1.04 \mathrm{f}$ & $1.08 \mathrm{~d}$ & $1.03 \mathrm{f}$ & 1.05 \\
\hline & $\mathbf{N}_{3}$ & $0.87 \mathrm{~h}$ & $0.96 \mathrm{~h}$ & $0.86 \mathrm{i}$ & 0.90 \\
\hline & Mean & 0.85 & 0.99 & 0.99 & 0.94 \\
\hline \multicolumn{2}{|c|}{ Grand mean } & 1.11 & 1.05 & 1.10 & \\
\hline
\end{tabular}

Means in the same column followed by the same letter are not significantly different at $P \leq 0.05$ 
Table.10 Nitrogen Derived from Fertilizer (g Lys-1) by Barley Straw as Affected by Water Regime, Nitrogen Rates and Splitting Strategy

\begin{tabular}{|c|c|c|c|c|c|c|c|c|}
\hline \multirow{3}{*}{$\begin{array}{l}\text { Water } \\
\text { regime }\end{array}$} & \multirow{3}{*}{$\begin{array}{l}\text { Nitrogen } \\
\text { rates }\end{array}$} & \multicolumn{7}{|c|}{ Splitting doses } \\
\hline & & \multicolumn{2}{|c|}{ S1 } & \multicolumn{2}{|c|}{ S2 } & \multicolumn{2}{|c|}{ S3 } & \multirow{2}{*}{$\frac{\text { Mean }}{\mathrm{g} \mathrm{Ly}^{-1}}$} \\
\hline & & $\%$ & $\mathbf{g L y}_{\mathbf{1}}^{-}$ & $\%$ & $\mathbf{g L y}_{1}^{-}$ & $\%$ & $\mathrm{gLy}_{1}^{-}$ & \\
\hline \multirow{4}{*}{ W1 } & N1 & 23.4 & 0.26 & 29.2 & 0.33 & 29.1 & 0.36 & 0.32 \\
\hline & $\mathbf{N} 2$ & 24.6 & 0.34 & 25.0 & 0.23 & 28.9 & 0.41 & 0.33 \\
\hline & N3 & 25.0 & 0.19 & 24.0 & $\mathbf{0 . 1 7}$ & 29.2 & 0.27 & 0.27 \\
\hline & Mean & & 0.26 & & 0.24 & & 0.35 & 0.29 \\
\hline \multirow{4}{*}{ W2 } & N1 & 23.2 & 0.37 & 27.9 & 0.24 & 28.7 & 0.26 & 0.29 \\
\hline & $\mathbf{N 2}$ & 25.0 & 0.35 & 28.8 & 0.20 & 29.4 & 0.22 & 0.26 \\
\hline & $\mathbf{N 3}$ & 28.0 & 0.20 & 29.4 & $\mathbf{0 . 1 7}$ & 29.8 & 0.20 & 0.19 \\
\hline & Mean & & 0.31 & & 0.20 & & 0.23 & 0.25 \\
\hline \multirow{4}{*}{ W3 } & N1 & 26.1 & 0.31 & 26.8 & 0.19 & 28.0 & 0.37 & 0.29 \\
\hline & $\mathbf{N} 2$ & 27.1 & 0.38 & 27.6 & 0.38 & 28.6 & 0.28 & 0.35 \\
\hline & N3 & 28.0 & 0.18 & 28.7 & 0.24 & 29.1 & 0.26 & 0.23 \\
\hline & Mean & & 0.29 & & 0.27 & & 0.30 & 0.29 \\
\hline
\end{tabular}

Table.11 Nitrogen Derived from Fertilizer (g Lys-1) by Barley Roots as Affected by Water Regime, Nitrogen Rates and Splitting Strategy

\begin{tabular}{|c|c|c|c|c|c|c|c|c|}
\hline \multirow{3}{*}{$\begin{array}{l}\text { Water } \\
\text { regime }\end{array}$} & \multirow{3}{*}{$\begin{array}{c}\text { Nitrogen } \\
\text { rates }\end{array}$} & \multicolumn{7}{|c|}{ Splitting doses } \\
\hline & & \multicolumn{2}{|c|}{ S1 } & \multicolumn{2}{|c|}{ S2 } & \multicolumn{2}{|c|}{ S3 } & Mean \\
\hline & & $\%$ & $\mathrm{gLy}^{-1}$ & $\%$ & $\mathrm{gLy}^{-1}$ & $\%$ & $\mathrm{gLy}^{-1}$ & $\mathrm{~g} \mathrm{Ly}^{-1}$ \\
\hline \multirow{4}{*}{ W1 } & N1 & 24.9 & 0.06 & 23.3 & 0.04 & 23.8 & 0.04 & 0.05 \\
\hline & $\mathbf{N} 2$ & 24.4 & 0.04 & 23.1 & 0.06 & 24.4 & 0.05 & 0.05 \\
\hline & N3 & 24.6 & 0.05 & 23.2 & $\mathbf{0 . 0 3}$ & 24.7 & 0.03 & 0.04 \\
\hline & Mean & & 0.05 & & 0.04 & & 0.04 & 0.05 \\
\hline \multirow{4}{*}{ W2 } & N1 & 22.4 & 0.04 & 22.1 & 0.03 & 25.0 & 0.06 & 0.04 \\
\hline & $\mathbf{N} 2$ & 23.1 & 0.03 & 24.2 & $\mathbf{0 . 0 3}$ & 28.3 & 0.04 & 0.03 \\
\hline & $\mathbf{N 3}$ & 24.8 & $\mathbf{0 . 0 3}$ & 24.9 & 0.02 & 29.1 & $\mathbf{0 . 0 3}$ & 0.03 \\
\hline & Mean & & 0.03 & & 0.03 & & 0.04 & 0.03 \\
\hline \multirow{4}{*}{ W3 } & N1 & 26.4 & 0.04 & 26.3 & 0.04 & 26.6 & 0.04 & 0.04 \\
\hline & $\mathbf{N} 2$ & 26.4 & 0.07 & 26.9 & 0.04 & 27.9 & 0.04 & 0.05 \\
\hline & N3 & 27.0 & 0.04 & 26.3 & $\mathbf{0 . 0 2}$ & 29.5 & 0.05 & 0.04 \\
\hline & Mean & & 0.05 & & 0.03 & & 0.04 & 0.04 \\
\hline
\end{tabular}


Table.12 Nitrogen Derived from Fertilizer (g Lys-1) by Barley Grains as Affected by Water Regime, Nitrogen Rates and Splitting Strategy

\begin{tabular}{|c|c|c|c|c|c|c|c|c|}
\hline \multirow{3}{*}{$\begin{array}{l}\text { Water } \\
\text { regime }\end{array}$} & \multirow{3}{*}{$\begin{array}{l}\text { Nitrogen } \\
\text { rates }\end{array}$} & \multicolumn{7}{|c|}{ Splitting doses } \\
\hline & & \multicolumn{2}{|c|}{ S1 } & \multicolumn{2}{|l|}{ S2 } & \multirow{2}{*}{$\begin{array}{r}\text { S3 } \\
\% \\
\end{array}$} & \multicolumn{2}{|c|}{ Mean } \\
\hline & & $\%$ & $\mathrm{gLy}^{-1}$ & $\%$ & $\mathrm{gLy}^{-1}$ & & $\mathrm{gLy}^{-1}$ & $\mathrm{~g} \mathrm{Ly}^{-1}$ \\
\hline \multirow{4}{*}{ W1 } & N1 & 22.7 & 0.30 & 27.1 & 0.36 & 31.6 & 0.47 & 0.38 \\
\hline & $\mathbf{N 2}$ & 22.7 & 0.31 & 27.5 & 0.39 & 30.9 & $\mathbf{0 . 3 0}$ & 0.33 \\
\hline & N3 & 23.7 & 0.29 & 28.5 & 0.40 & 30.9 & 0.26 & 0.32 \\
\hline & Mean & & 0.30 & & 0.38 & & 0.34 & 0.34 \\
\hline \multirow{4}{*}{ W2 } & N1 & 22.5 & 0.28 & 22.7 & 0.17 & 32.7 & 0.42 & 0.29 \\
\hline & $\mathbf{N} 2$ & 23.3 & 0.29 & 22.1 & 0.23 & 32.4 & 0.40 & 0.31 \\
\hline & N3 & 23.9 & 0.24 & 22.2 & 0.20 & 31.7 & 0.36 & 0.27 \\
\hline & Mean & & 0.27 & & 0.20 & & 0.39 & 0.29 \\
\hline \multirow{4}{*}{ W3 } & N1 & 22.5 & 0.14 & 23.3 & 0.22 & 28.6 & 0.30 & 0.22 \\
\hline & $\mathbf{N} 2$ & 22.3 & 0.23 & 23.1 & 0.25 & 28.8 & 0.30 & 0.26 \\
\hline & N3 & 24.9 & 0.22 & 23.2 & 0.22 & 28.0 & 0.24 & 0.23 \\
\hline & Mean & & 0.20 & & 0.23 & & 0.28 & 0.24 \\
\hline
\end{tabular}

Table.13 Efficient use of Nitrogen Fertilizer (\%NUE) by Barley Straw, Roots and Grains as Affected by Water Regime, Nitrogen Rates and Splitting Strategy

\begin{tabular}{|c|c|c|c|c|c|c|c|c|c|c|c|c|c|}
\hline \multirow{3}{*}{$\begin{array}{l}\text { Water } \\
\text { regime }\end{array}$} & \multirow{3}{*}{$\begin{array}{c}\text { Nitrogen } \\
\text { rates }\end{array}$} & \multicolumn{12}{|c|}{ Splitting doses } \\
\hline & & S1 & S2 & S3 & Mean & S1 & S2 & S3 & Mean & S1 & $\mathbf{S 2}$ & S3 & Mean \\
\hline & & \multicolumn{4}{|c|}{ Straw } & \multicolumn{4}{|c|}{ Roots } & \multicolumn{4}{|c|}{ Grains } \\
\hline \multirow{4}{*}{ W1 } & N1 & 37.0 & 47.0 & 51.0 & 45.0 & 8.6 & 5.7 & 5.7 & 6.7 & 42.9 & 51.4 & 67.1 & 53.8 \\
\hline & $\mathbf{N} 2$ & 39.0 & 26.0 & 47.0 & 37.3 & 4.6 & 6.8 & 5.7 & 5.7 & 35.4 & 44.5 & 34.2 & 38.0 \\
\hline & N3 & 18.0 & 16.0 & 26.0 & 20.0 & 4.8 & 2.9 & 2.9 & 3.5 & 27.6 & 38.1 & 24.8 & 30.2 \\
\hline & Mean & 31.3 & 29.7 & 41.3 & 34.1 & 6.0 & 5.1 & 4.8 & 5.3 & 35.3 & 44.7 & 42.0 & 40.7 \\
\hline \multirow{4}{*}{ W2 } & N1 & 53.0 & 34.0 & 37.0 & 41.3 & 5.7 & 4.3 & 8.6 & 6.2 & 40.0 & 24.3 & 60.0 & 41.4 \\
\hline & $\mathbf{N} 2$ & 40.0 & 23.0 & 25.0 & 29.3 & 3.4 & 3.4 & 4.6 & 3.8 & 33.1 & 26.3 & 45.7 & 35.0 \\
\hline & N3 & 19.0 & 16.0 & 19.0 & 18.0 & 2.9 & 1.9 & 2.9 & 2.6 & 22.9 & 19.0 & 34.3 & 25.4 \\
\hline & Mean & 37.3 & 24.3 & 27.0 & 29.5 & 4.0 & 3.2 & 5.4 & 4.2 & 32.0 & 23.2 & 46.7 & 33.9 \\
\hline \multirow{4}{*}{ W3 } & N1 & 44.0 & 27.0 & 53.0 & 41.3 & 5.7 & 5.7 & 5.7 & 5.7 & 20.0 & 31.4 & 42.9 & 31.4 \\
\hline & $\mathbf{N} 2$ & 43.0 & 43.0 & 32.0 & 39.3 & 8.0 & 4.6 & 4.6 & 5.7 & 26.3 & 28.5 & 34.2 & 29.7 \\
\hline & N3 & 17.0 & 23.0 & 25.0 & 21.7 & 3.8 & 1.9 & 4.8 & 3.5 & 20.9 & 20.9 & 22.9 & 21.5 \\
\hline & Mean & 34.7 & 31.0 & 34.7 & 34.1 & 5.8 & 4.1 & 5.0 & 5.0 & 22.4 & 26.9 & 33.3 & 27.5 \\
\hline
\end{tabular}

Likewise, nitrogen uptake by different barley parts was significantly higher with $\mathrm{N} 2$ rate $\left(156 \mathrm{~kg} \mathrm{~N} \mathrm{ha}^{-1}\right)$ combined with $\mathrm{W} 1$ $(550 \mathrm{~mm})$ than those of $\mathrm{N} 1\left(187.2 \mathrm{~kg} \mathrm{~N} \mathrm{ha}^{-1}\right)$ or N3 (124.8 $\left.\mathrm{kg} \mathrm{N} \mathrm{ha}^{-1}\right)$ under W2 (440 mm) or W3 $(330 \mathrm{~mm})$ which considered as stress water regimes. These results are nearly closed to those reported by Li-min et al. (2015) who stated that nitrogen used (NU) by wheat from low rate of urea nitrogen was 
significantly lower than that of the high rate of $\mathrm{N}$. The NU of wheat grown under W1 $(500 \mathrm{~mm})$ irrigation was higher than that under W2 $(350 \mathrm{~mm})$ irrigation. They observed a significant interaction between water and nitrogen fertilizer in wheat production of GY. Also, they explained that water deficit could therefore restrict the effectiveness of $\mathrm{N}$ fertilizer and over irrigation may result in loss of nitrates to leaching, leading ultimately to a decrease in wheat yields. Excessive or deficient application of $\mathrm{N}$ fertilizer will hamper the improving efficiencies of water and nitrogen use. Deficit water irrigation was unable to satisfy the plants' water requirements, which means that water became the limiting factor to wheat growth, and the promoting effect of $180 \mathrm{~kg} \mathrm{~N} \mathrm{ha}^{-1}$ to $90 \mathrm{~kg} \mathrm{~N} \mathrm{ha}^{-1}$ was restricted.

As demonstrated by Drechsel et al. (2015), the improvements in nutrient use efficiency should not be viewed only as fertilizer management. For example, the processes of nutrient accumulation or depletion are often related to transport processes in water. The interaction of water and nutrients in soil fertility management is governed by the following considerations: 1) Soil water stress will limit soil nutrient use at the plant level, 2) Soil-supplied nutrients can be taken up by plants only when sufficient soil solution allows mass flow and diffusion of nutrients to roots, 3) Soil water content is the single most important factor controlling the rate of many chemical and biological processes, which influence nutrient availability. On the other hand, poor soil fertility limits the ability of plants to efficiently use water (Bossio et al., 2008).

In the same direction, Mikkelsen et al., (2012) define that the objective of nutrient use is to increase the overall performance of cropping systems by providing economically optimum nourishment to the crop while minimizing nutrient losses from the field and supporting agricultural system sustainability through contributions to soil fertility or other components of soil quality. NUE addresses some, but not all, aspects of that performance. The most valuable NUE improvements are those contributing most to overall cropping system performance. Nitrogen recovered by barley crop showed significant correlation with water regime and nitrogen added rates or splitting modes. In this regard, Thomsen and Jensen (1994) estimated $4.5 \%$ of labeled straw recovered by barley straw. On the other hand, they recorded 29-40\%, which considered relatively low, of ${ }^{15} \mathrm{NH}_{4}{ }^{15} \mathrm{NO}_{3}$ applied during the year of vegetation.

In a field experiment with wheat, Ichir et al. (2003), demonstrated trends of interaction between water regimes and nitrogen fertilizer rates applied in different splitting doses in relation to plant growth curve, nearly closed to those we have. They found that nitrogen fertilization with $168 \mathrm{~kg} \mathrm{Nha}^{-1}$ did no significantly increase grain and straw yields in comparison to the $126 \mathrm{~kg} \mathrm{Nha}^{-1}$ application. The combination of the organic input and supplementary application of mineral fertilizer $\mathrm{N}$ has been found as a more attractive management option. For all irrigation treatments, the \% recovery of $\mathrm{N}$ in the whole plant was higher in plants that received ${ }^{15} \mathrm{~N}$ at tillering $(63 \%, 49 \%$ respectively for irrigation intervals between 10 and $30 \mathrm{~d}$ ) than in plants that received ${ }^{15} \mathrm{~N}$ just after seeding (28\% for irrigation each 10 - and 30-d intervals). For the irrigation treatment each 10 and 15 days, the $\mathrm{N}$ was mainly recovered by the grain for all fertilization treatments, whereas for irrigation treatment each 30 days, the grain and straw recovered nearly equal amounts of fertilizer. For grain and straw of wheat, nitrogen in the plant derived from the fertilizer was low, while most of the $\mathrm{N}$ was 
derived from the soil for all irrigation and fertilization treatments. The $\%$ nitrogen in the plant derived from the fertilizer values showed no significant difference between the different plant parts. Their results suggested a dominant influence of moisture availability on the fertilizer $\mathrm{N}$ uptake by wheat. A 3-year field experiment in rainfed Vertisol was designed by López-Bellido et al. (2005), to study the effects of timing and splitting of $\mathrm{N}$ fertilizer on the efficiency of nitrogen in wheat (Triticum aestivum L.). A single rate of $150 \mathrm{~kg} \mathrm{~N} \mathrm{ha}{ }^{-1}$ was used, different fractions being applied at sowing, tillering and stem elongation. Mean wheat use of $\mathrm{N}$ fertilizer ranged from $14.1 \%$ when applied at sowing to $54.8 \%$ when applied as a top dressing at the beginning of stem elongation. Our \%NUE obtained with different barley parts are nearly closed to those abovementioned. It seems that splitting doses correlated with plant growth curve and could be recommended as strategy from the standpoint both of the environment and of farmer returns.

Recently, Ouda et al. (2015) found that maize grown on sandy soil and exposed to two climate change scenarios and irrigated with an amount of either 1.2 or 0.8 of ETc with fertigation application in $80 \%$ of application time are recommended to enhance the water productivity (WP) and reduce maize's damage caused by extreme climate change. They added that Improvement of water management for maize grown in sandy soil irrigated with drip irrigation under climate change, fertigation should be used to apply fertilizer in $80 \%$ of the irrigation time, with irrigation amount of either 1.2 or 0.8 ETc. This practice is recommended to enhance WP and reduce maize's damage caused by extreme climate change. On line, our results are nearly closed to those obtained by Barati et al. (2015) who planted two barley cultivars in silty clay soil under semi-arid Mediterranean conditions and fertilized with three nitrogen fertilizer rates $(0,60$ and 120 $\mathrm{kg} \mathrm{N} \mathrm{ha}{ }^{-1}$ ) and three water regimes, i.e. $100 \%, 75 \%$ and $50 \%$ of the full-irrigation, $\mathrm{I}_{100}, \mathrm{I}_{75}$ and $\mathrm{I}_{50}$, respectively. They achieved the highest NUE (40.2) in $\mathrm{N}_{0}$ and $\mathrm{I}_{100}$ conditions. Under similar conditions, optimum grain yield might be achieved by 120 and $60 \mathrm{~kg} \mathrm{~N} \mathrm{ha}^{-1}$ at $\mathrm{I}_{100}$ and water shortage conditions, respectively. The highest grain yield was achieved by 120 and $60 \mathrm{~kg} \mathrm{~N} \mathrm{ha}^{-1}$ under $\mathrm{I}_{100}$ and drought stress conditions, respectively. They concluded that optimizing irrigation and $\mathrm{N}$ rates and selection of suitable cultivars in semi-arid Mediterranean climate might increase NUE, WUE and produce economic grain yield.

\section{References}

Barati V., Ghadiri H., Zand-Parsa Sh. and Karimian N. (2015) Nitrogen and water use efficiencies and yield response of barley cultivars under different irrigation and nitrogen regimes in a semi-arid Mediterranean climate, Archives of Agronomy and Soil Science, 61:1, 15-32.

Bossio, D., Noble, A., Molden, D., Nangia, V. (2008) Land degradation and water productivity in agricultural landscapes. In Conserving land, protecting water, ed., Bossio, D.; Geheb, K. Wallingford, UK: CABI; Colombo, Sri Lanka: International Water Management Institute (IWMI); Colombo, Sri Lanka: CGIAR Challenge Program on Water and Food, pp.20-32. (Comprehensive Assessment of Water Management in Agriculture Series 6).

Carter, M.R. and Gregorich, E.G. (2008) Soil sampling and methods of analysis. (2nd ed.), CRC Press Taylor \& Francis Group, 6000 Broken Sound 
Parkway NW, Suite 300 Boca Raton, FL, p. 1224.

Cossani, C.M., Savin, R., Slafer, G.A., (2007) Contrasting performance of barley and wheat in a wide range of conditions in Mediterranean Catalonia (Spain). Annals of Applied Biology 151, 167-173.

Cossani, C.M., Slafer, G.A., Savin, R., (2009) Yield and biomass in wheat and barley under a range of conditions in a Mediterranean site. Field Crops Research 112, 205-213.

Cui, Z.L., Chen, X.P., Zhang, F.S., Xu, J.F., Shi, L.W., Li, J.L., (2007) Appropriate soil nitrate $\mathrm{N}$ content for a winter wheat/summer maize rotation system in North China Plain. Chin. J. Appl. Ecol., 2227-2232 (in Chinese).

Dang, T.H., Qi, L.H., Guo, S.L., Hao, M.D., (2009) Relationship between soil nitrate nitrogen balance and utilization in rainfed land. Plant Nutr. Fertil. Sci. 15, 573-577.

Drechsel P., Heffer P., Magen H., Mikkelsen R., Singh H. and Wichelns D. (2015) Managing water and nutrients to ensure global food security, while sustaining ecosystem services. In: Drechsl et al., eds. Managing Water and Fertilizer for Sustainable Agricultural Intensification, International Fertilizer Industry Association (IFA), International Water Management Institute (IWMI), International Plant Nutrition Institute (IPNI), and International Potash Institute (IPI) Paris, France, January 2015, p. 1-7.

Fan, J., Hao, M.D., Shao, M.A., (2003) Nitrate accumulation in soil profiles of dry land farming in Northwest China. Pedosphere 13, 367-374.

Fan, J., Hao, M.D., Shao, M.A., Wang, Q.J., (2005) Nitrate accumulation and distribution in soil profiles in ecosystem of upland on the Loess Plateau. Plant Nutr. Fertil. Sci. 11, 812 (in Chinese).

Ferguson, R.B., Hergertb, G.W., Schepersc, J.S., Gotwayd, C.A., Cahoone, J.E., Petersonf, T.A., (2002) Site-specific nitrogen management of irrigated maize yield and soil residual nitrate effects. Soil Sci. Soc. Am. J. 66, 544553.

Ferrante, A., Savin, R., Slafer, G.A., (2013) Floret development and grain setting differences between modern durum wheats under contrasting nitrogen availability. Journal of Experimental 64, 169-184.

Gao, Y.J., Li, Y., Li, S.X., Qiang, Q., Cao, W.X., Liu, W.G., Zhang, J.C., Dang, Z.P., Liu, J.H., (2005) Effects of different wheat cultivation methods on residual nitrate nitrogen. Acta Ecol. Sin. 25 (11), 2901-2909.

Hall, A. J., Savin, R. and Slafer, G.A. (2014) Is time to flowering in wheat and barley influenced by nitrogen?: A critical appraisal of recent published reports. Europ. J. Agronomy 54: 4046.

Hartmann T. E., Yue Sh., Schulz R., He X., Chen X., Zhang F. and Müller T. (2015) Yield and $\mathrm{N}$ use efficiency of a maize-wheat cropping system as affected by fertilizer management strategies in a farmer's field of the North China Plain. Field Crops Res, 174, 30-39.

IAEA, Vienna (2001) Use of isotope and radiation methods in soil and water management and crop nutrition. Manual.Training course series No.14. IAEA, Vienna.

Ichir L.L., Ismaili M. and Van Cleemput O. (2003) Effect of organic and mineral fertilizers on $\mathrm{N}$-use by wheat under different irrigation frequencies. C. R. Biologies 326, 391-399. 
Ju, X.T., Xing, G.X., Chen, X.P., Zhang, S.L., Zhang, L.J., Liu, X.J., Cui, Z.L., Yin, B., Christie, P., Zhu, Z.L., Zhang, F.S., (2009) Reducing environmental risk by improving $\mathrm{N}$ management in intensive Chinese agricultural systems. Proc. Natl. Acad. Sci. U. S. A. 106, 3041-3046.

Li Sh-Xi, Wang Z-H, Malhi S. S., Li Shi-Qi, Gao Ya-Jun, and Tian Xi-H (2009) Nutrient and water management effects on crop production, and nutrient and water use efficiency in dryland areas of China. Advances in Agronomy, Volume 102, 223-265.

Li, S.X., Wang, Z.H., (2006) Dryland agriculture in Eastern Asia. In: Peterson, G.A., Unger, P.W., Payne, W.A. (Eds.), Dryland Agriculture., 2nd edition. American Society of Agronomy, Crop Science Society of America, Soil Science Society of America, 677 S. Segue Rd., Madison, WI 53711, USA, pp. 671-731 (Agronomy Monograph no. 23).

Li, S.X., Wang, Z.H., Hu, T.T., Gao, Y.J., Stewart, B.A., (2009) Nitrogen in dryland soils of China and its management. Adv. Agron. 101, $123-$ 181.

Li-min GU, Tie-ning Liu, Zhao Jun, Dong Shu-ting, Liu Peng, Zhang Ji-wang, Zhao Bin (2015) Nitrate leaching of winter wheat grown in lysimeters as affected by fertilizers and irrigation on the North China Plain Journal of Integrative Agriculture, 14(2): 374 388.

Liu, D.Q., Tong, Y.A., Sun, B.H., Emteryd, O., (1998) Study on effect of nitrogen fertilizer use on environmental pollution. Plant Nutr. Fertil. Sci. 4, 815 (in Chinese).

Liu, X.J., Zhao, Z.J., Ju, X.D., Zhang, F.S., (2002) Effect of $N$ application as basal fertilizer on grain yield of winter wheat, fertilizer $\mathrm{N}$ recovery and $\mathrm{N}$ balance. Acta Ecol. Sin. 22 (7), 11221128 (in Chinese).

López-Bellido L., López-Bellido R. J., and Redondo R. (2005) Nitrogen efficiency in wheat under rainfed Mediterranean conditions as affected by split nitrogen application. Field Crops Research 94, 86-97.

Miao, Y,-F., Wang, Z,-H. and Li S,-X. (2015) Relation of nitrate N accumulation in dryland soil with wheat response to $\mathrm{N}$ fertilizer. Field Crops Res. 170: 119-130.

Mikkelsen, Rob, Jensen, Tom L., Snyder, Cliff, Bruulsema, Tom W. (2012) Chapter 9. Nutrient management planning and accountability. In Bruulsema, T.W., Fixen, P.E., Sulewski, G.D. (eds.), 4R Plant nutrition: A manual for improving the management of plant nutrition. Norcross, GA, USA: International Plant Nutrition Institute.

$\mathrm{Ni}$, Y.X., Yin, X., Liu, X.Y., Ju, X.T., Zhang, L.J., (2013) Exploration of N fertilizer fate and quantitative soil nitrogen pool budget in growing season of winter wheat in North China Plain. Ecol. Environ. Sci. (3), 392-397 (in Chinese).

Ouda S. A., Taha A. M. and Ibrahim M. M. (2015) Water management for maize grown in sandy soil under climate change conditions, Archives of Agronomy and Soil Science, 61:3, 299-311.

Pan, J.R., Ju, X.T., Liu, X.J., Chan, X.P., Zhang, F.S., Mao, D.R., (2009) Fate of fertilizer Nitrogen for winter wheat/summer maize rotation in North China Plain under optimizations of irrigation and fertilization. J. Nucl. Agric. Sci. (2), 334-340 (in Chinese).

Pen, L., Pen, X.L., Lu, Z.F., (1981) The seasonal variation of soil $\mathrm{NO}_{3}^{-}-\mathrm{N}$ and 
the effect of summer fallow on the fertility of loessial soil. Acta Pedol. Sin. 18, 212-222 (in Chinese).

Robertson, L. D. and Stark, J. C. (2003) Idaho Spring Barley Production Guide. (C) 2003 University of Idaho, pp. 60.

Ryan, J., Singh, M., Pala, M., (2008) Longterm cereal-based rotation trials in the Mediterranean region: implications for cropping sustainability. Advances in Agronomy 97, 273-319.

SAS (2002) The SAS System for Windows. Release 9. 0. SAS Inst. Inc., Cary, NC.

Stark, J. C. and Brown, B. D. (2003) Nutrient Management. In: Robertson, L. D. and Stark, J. C. (Edts.) Idaho Spring Barley Production Guide. (C) 2003, p.22-26.

Temminghoff E. E.J.M. and Houba V. J.G. (2004) Plant Analysis Procedures. Second Edition, Kluwer Academic Publishers Dordrecht / Boston / London, pp. 187.

Thomsen I.K., Jensen E.S. (1994) Recovery of nitrogen by spring barley following incorporation of ${ }^{15} \mathrm{~N}$-labelled straw and catch crop material. Agriculture, Ecosystems and Environment 49, 115122.

Tong, Y.A., Shi, W., Lu, D.Q., Emteryd, O., (2005) Relationship between soil texture and nitrate distribution and accumulation in three types of soil profile in Shaanxi. Plant Nutr. Fertil. Sci. 11, 435-441 (in Chinese).

Van Herwanarden, A.F., Angus, J.F., Richards, R.A., Farquhar, G.D., (1998) 'Haying-off', the negative grain yield response of dryland wheat to nitrogen fertilizer I. Biomass, grain yield, and water use. Australian Journal of Agricultural Research 49, 1067-1081.

Wang, C.Y., Zhou, J.B., Zheng, X.F., Li, S.X., (2007) Effects of different cultivation methods on soil residual nitrate under winter wheat-summer maize cropping system. Plant Nutr. Fertil. Sci. 13 (6), 991-997.

Wang, Z.H., Li, S.X., Wang, X.N., Su, T., (2006) Nitrate nitrogen residue and leaching in dryland soil and influence factors. Soils 38, 676-686 (in Chinese).

Wei, F.Z., Li, J.C., Wang, C.Y., Qiu, H.J., (2010) Effects of nitrogen application model on min nitrogen absorption and utilization in winter wheat. J. Triticeae Crop. 30, 123-128 (in Chinese).

Yang, Y.H., Zhang, R.Z., (2006) Effects of nitrogen fertilization on the distribution and accumulation of nitrate in soil in semiarid areas of the Loess Plateau. Gansu Agric. Univ. 41 (1), 102-107.

\section{How to cite this article:}

Samak, R.R. Magdy, El.I. Gaber, Y.G.M. Galal and Mohamed, M.A. 2016. Barley Nitrogen Acquisition as Affected by Water Regime, Fertilizer Rates and Application Mode Using 15N Stable Isotope. Int.J.Curr.Microbiol.App.Sci. 5(1): 116-135. doi:'ihttp://dx.doi.org/10.20546/ijcmas.2016.501.010 